\title{
Program "SAHABAT" Sebagai Salah Satu Program Alternatif Penanganan Bullying Pada Anak Usia Dini
}

\author{
Iswatun Khasanah \\ itsmeiswa@yahoo.co.id \\ KB Ay-Yumna, Dukuh, Imogiri, Imogiri, Bantul
}

\begin{abstract}
Abstrak
Permasalahan anak khususnya bullying seringkali terjadi di Tk. terdapat beberapa faktor yang mempengaruhunya, diantaranya karena faktor lingkungan. Anak melakukan bullying karena meniru atau imitasi dari lingkungan terdekatnya. Penanganan bullying dirasa masih belum optimal. Pelaku dan korban perlu diberikan pendampingan secara intensif. "Program SAHABAT" Sebagai Salah Satu Alternatif Penanganan Bullying Pada Anak Usia Dini (Usia 5-6 Tahun) bertujuan untuk memberikan pengetahuan bagi guru dan orang tua mengenai penanganan bullying dan cara mengaplikasikannya. Dengan adanya Program SAHABAT guru dan orang tua dapat memperkuat wawasan dan pemahaman serta mengaplikasikan program SAHABAT sebagai salah satu altenatif dalam menangani bullying pada anak, sehingga perkembangan sosial emosional anak dapat berkembang dengan baik.
\end{abstract}

Kata Kunci: program sahabat, bullying, anak usia dini

\section{Abstract}

Problems especially children bullying often happens in Kindergarten. There are several factors that memperngaruhunya, such as environmental factors. Child doing the bullying

- because it mimics or imitation of its immediate environment. Handling bullying it is still not optimal. Perpetrators and victims should be given intensive assistance. "SAHABAT of the Program" as one alternative handling bullying in early childhood (age 5-6 years) aims to provide knowledge for teachers and parents regarding the handling of bullying and how to apply it. Through this program, teachers and parents can reinforce and apply insight and understanding FRIENDS program as one alternative in dealing with bullying in children, so the social emotional development of children can thrive.

Keywords: companion program, bullying, early childhood

Pendahuluan

Anak usia dini adalah investasi masa depan bagi keluarga dan bangsa. Nantinya, anak usia dini akan menjadi orang-orang yang akan membangun bangsa Indonesia menjadi bangsa yang maju dan tidak tertinggal dari bangsabangsa lain. Dengan kata lain, masa depan bangsa sangat ditentukan oleh pendidikan yang diberikan kepada anak usia dini. Di Indonesia, pendidikan yang diperuntukkan untuk anak usia 0-6 tahun ini dikenal sebagai Pendidikan Anak Usia Dini (PAUD).
Pendidikan anak usia dini menjadi pendidikan yang penting bagi seorang anak. Hal ini berkaitan dengan masa pertumbuhan dan perkembangan otak anak yang sudah mencapai $80 \%$ pada usia 6 tahun. Pada usia tersebut segala sesuatu yang diterima anak akan dapat memberikan bekas yang kuat dan tahan lama. Kesalahan dalam mendidik anak akan memberikan efek negatif jangka panjang yang sulit diperbaiki (Slamet Suyanto, 2005:2). Oleh karena itu anak perlu diberi rangsangan yang tepat untuk tumbuh kembangnya. Dalam tumbuh 
kembangnya ada berbagai kebutuhan yang perlu dipenuhi seperti diajak bermain bebas, memberikan kesempatan bagi anak untuk berbicara, diajak berdiskusi, diperlakukan dengan penuh kasih sayang, perhatian, rasa aman, dan penghargaan terhadap diri mereka sendiri, sehingga anak dapat mengembangkan seluruh kemampuan yang dimilikinya.

Anak usia dini berkembang dengan seluruh potensi yang ada di dalam dirinya. Aspek perkembangan anak salah satunya adalah perkembangan sosial emosional anak. Perkembangan sosial emosional anak berkaitan dengan kemampuan anak untuk berinteraksi dengan orang lain, menyesuaikan diri dengan lingkungan, dan kemampuan pengendalian diri. Perkembangan sosial emosional meliputi dua aspek penting, yaitu kompetensi sosial dan tanggung jawab sosial (Kostelnik, dkk dalam Slamet Suyanto, 2005: 70). Kompetensi sosial menggambarkan kemampuan anak untuk beradaptasi dengan lingkungan sosialnya secara efektif.

Permasalahan perkembangan sosial emosional ditandai dengan munculnya perilaku anak yang kurang tepat baik di sekolah maupun dirumah. Perilaku tersebut seperti memukul, mendorong, mencubit, mencakar dan merusak barang milik orang lain. Selain itu mengejek teman, mengancam, menjulurkan lidah dan memanggil nama teman menggunakan julukan tertentu seperti "si gendut", si item", dan "si kurus". Tidak menutup kemungkinan, ketika anak beradaptasi dengan lingkungan sosialnya anak melakukan imitasi yang mempengaruhi perilaku anak salah satunya adalah bullying.

Berdasarkan hasil wawancara dengan beberapa guru di TK, umumnya perilaku bullying yang sering terjadi adalah saling mengolok atau mengejek, suka memukul, suka berkata kasar terhadap temannya, cenderung bersifat kasar pada anak-anak lain waktu mereka bermain, suka berargumen, tidak menaati peraturan kelas maupun guru, tidak sabar menunggu giliran, merusak mainan milik anak lain, mencubit, menjulurkan lidah, memberi panggilan nama (name-calling) dan mendiamkan anak lain. Melihat berbagai macam perilaku tersebut pendidik berusaha untuk mengatasi perilaku anak, akan tetapi pendidik cenderung memarahi anak dan menunjukkan kesalahan yang telah dilakukan oleh anak tanpa memberikan suatu penguatan agar anak tidak melakukan perbuatan itu lagi. Perlu diingat bahwa ketika pendidik marah maka secara tidak langsung anak juga belajar bagaimana anak harus bersikap ketika mereka marah.

\section{Pengertian Bullying}

Ken Rigby (2008: 3) mengatakan bahwa bullying adalah sebuah hasrat untuk menyakiti. Hasrat ini diperlihatkan ke dalam aksi, menyebabkan seorang menderita. Aksi ini dilakukan secara langsung oleh seseorang atau kelompok yang lebih kuat, tidak bertanggung jawab, biasanya berulang dan dilakukan dengan perasaan senang. Berdasarkan penelitian dari beberapa ahli, salah satunya oleh Rigby, bullying yang banyak dilakukan di sekolah umumnya mempunyai tiga karakteristik yang terintegrasi sebagai berikut: (1) adanya perilaku agresi yang meyenangkan pelaku untuk menyakiti korbannya, (2) tindakan itu dilakukan secara tidak seimbang sehingga menimbulkan perasaan tertekan korban, (3) perilaku itu dilakukan secara berulang atau terus menerus.

\section{Macam-Macam Bullying}

Terdapat lima macam kategori . bullying yaitu:

1. Kontak fisik langsung (memukul, mendorong, mencubit, mencakar, juga termasuk memeras dan merusak barang-barang yang mlik orang lain).

2. Kontak verbal langsung (mengancam, mempermalukan, merendahkan, mengganggu, memanggil orang lain 
dengan julukan tertentu (name calling), merendahkan (put-down), mencela, mengintimidasi, mengejek, dan menyebarkan gosip).

3. Perilaku non-verbal langsung (melihat dengan sinis, menjulurkan lidah, menampilkan ekspresi muka yang merendahkan, mengejek, atau mengancam, biasanya disertai oleh bullying fisik atau verbal).

4. Perilaku non verbal tidak langsung (mendiamkan seseorang, memanipulasi persahabatan sehingga menjadi retak, sengaja mengucilkan atau mengabaikan, mengirimkan surat kaleng).

\section{Faktor Penyebab Perilaku Bullying}

Perilaku bullying pada anak disebabkan karena dua faktor. Menurut Egi

(http://regianamanah.blogspot.com/2011/0 2/perilaku-bullying-pada-anak-

sekolah.html) yang bisa menyebabkan anak berperilaku bully adalah perpaduan dari faktor internal dan eksternal.

1. Faktor Internal (dalam)

a. Harga diri anak

Harga diri adalah penilaian yang dibuat seseorang tentang dirinya. Hal itu menyatakan sikap menyetujui atau tidak menyetujui, dan menunjukkan sejauh mana orang menganggap dirinya mampu dan berarti. Terkadang, anak melakukan bullying karena anak ingin orang lain menganggap dirinya "super" sehingga ditakuti oleh orang lain.

b. Pemahaman moral anak yang rendah

Berbagai perilaku menyimpang yang dilakukan anak ditengarai disebabkan oleh minimnya pemahaman anak terhadap nilai diri yang positif. Sikap saling menghargai, menolong, berempati, jujur, lemah lembut dan sebagainya tidak jarang hilang dari pribadi anak. Sebaliknya, mereka justru akrab dengan hal-hal yang negatif seperti kekerasan, kebohongan, licik, egois dan sebagainya.
Harga diri yang rendah dan pemahaman moral anak yang rendah memunculkan perilaku bullying. Anak yang melakukan bullying pada temannya karena anak ingin mendapatkan perhargaan dari temannya ataupun ingin teman-temannya menganggapnya sebagai seseorang yang "super" sehingga teman-temannya takut dan segan pada pelaku bullying.

2. Faktor Eksternal (luar)

a. Sikap orang tua

Anak bisa meniru perilaku buruk yang dilihat dari perilaku kedua orang tuanya. Selain itu lingkungan juga dapat memberikan penguatan atau reinforcement pada anak untuk bersikap bully. Bukan hanya itu, sebenarnya lingkungan yang mengabaikan atau mentolerir sikap bully anak juga dapat menjadi penguat. Orangtua yang tidak berbuat apa-apa akan membuat anak merasa bahwa tindakannya tidak salah.

b. Keluarga yang memanjakan

Anak berperilaku bullying itu biasanya datang dari beberapa macam keluarga. Pertama, keluarga yang sangat memanjakan anak. Apa pun keinginan anak dituruti, sehingga anak merasa bisa mengatur orang lain sesuka hati. Akibatnya anak menjadi terlalu percaya diri dan tidak menutup kemungkinan anak akan menindas ataupun memanfaatkan teman-temannya.

c. Ketegasan

Perilaku bullying juga bisa terjadi karena tidak adanya ketegasan dari orang tua. Orang tua yang tidak memiliki ketegasan dan konsistensi terhadap aturan yang diberlakukan pada anak. Misalnya, orang tua selalu mengingatkan anak untuk tidak berkata buruk terhadap temannya akan tetapi terkadang orang tua secara tidak sengaja melakukan hal tersebut pada anak.

d. Tayangan televisi

Membiarkan anak bersama televisi hanya akan membuat tenang sementara, 
tetapi bahaya yang mengintainya jauh lebih besar. Hal ini terjadi karena stasiun televisi sekarang ini semakin bebas menyiarkan berita di samping terbatasnya siaran yang boleh ditonton semua umur. Padahal tidak semua tayangan anak, terutama film kartun, cocok untuk dikonsumsi anak-anak. Ada beberapa tayangan televisi yang memperlihatkan perilaku kekerasan sehingga ditiru oleh anak. Idealnya, anak cukup menonton televisi selama 23 jam sehari, selebihnya dialihkan pada kegiatan lain. Bahan tontonan sebaiknya harus melalui sensor orang tua. Orang tua harus lebih peka memilih mana tontonan yang cocok untuk anakanak dan mana yang tidak. Kata kuncinya adalah orang tua menyeleksi, mendampingi, dan mengarahkan pada waktu anak menonton tayangan televisi (Jenny Gichara, 2006).

\section{Dampak Bullying}

Anak-anak yang menjadi korban ${ }^{\circ}$ bullying umumnya memiliki perasaan tidak berdaya, takut, dan terancam. Kondisi ini menyebabkan kepercayaan turun, malu, trauma, tak mampu menyerang balik, merasa sendiri, serba salah, dan takut sekolah (school phobia), dimana ia merasa tak ada yang menolong. Sedangkan pelaku bullying menjadi tidak empati, egois, dan dijauhi teman.

Berdasarkan berbagai macam permasalahan bullying salah satu penanganannya dapat dilakukan melalui program SAHABAT.

\section{Program Sahabat}

Program SAHABAT merupakan salah satu cara untuk menangani masalah bullying pada anak usia dini. Ken Rigby (Ponny Retno A, 2008: 40) mengemukakan program ini menitikberatkan tema yang mengutamakan metode intervensinya dengan menggunakan unsur nilai-nilai etika, yaitu $\begin{array}{lrr}\text { Kasih Sayang } & \text { (love), } & \text { Harmonis } \\ \text { (Harmoni), } & \text { Tanggung } & \text { Jawab }\end{array}$
(Responsibility), Baik Budi (Kind), dan Persatuan (Unity). Program SAHABAT melibatkan semua pihak yang berada di sekolah, termasuk orang tua, guru, staf, siswa, dan komunitas sekolah untuk proaktif menjadi bagian dalam kegiatan dan pengawasan sekolah.

Poin pertama, kasih sayang (love).

Kasih sayang atau cinta merupakan sendi dasar Program SAHABAT. Kedua kata tersebut mengandung makna berbagi, ramah, menjaga dan memperhatikan, nyaman, menghilangkan emosi kemarahan, ingin hal-hal terbaik untuk orang lain. Kasih sayang bisa diwujudkan dalam bentuk perbuatan, pikiran, dan semangat yang dilakukan dengan kesadaran serta dapat ditujukan untuk siapapun. Kriteria kasih sayang pada program SAHABAT ini lebih menekankan pada kasih sayang terhadap sesama yang tidak bersifat membedakan. Jika anak diberikan kasih sayang maka anak akan tumbuh menjadi anak yang menyayangi orang lain dan memiliki rasa empati. Misalnya ketika terjadi salah satu perilaku bullying yaitu anak memukul temannya, guru atau orang tua hendaknya memberikan perhatian dan menghilangkan emosi kemarahan tidak hanya pada korban tetapi juga kepada pelaku bullying.

Poin kedua, harmoni. Memahami hakikat harmoni adalah memahami hidup bersama yang damai, toleran, tenang, saling menghargai, dan saling berbagi. Dalam konsep Jawa makna harmoni menjadi bagian dari prinsip kehidupan Jawa yang wajib dijalankan. Oleh karenanya, prinsip-prinsip hidup ideal yang hakiki seperti damai, toleran, tenang, saling menghargai, adil, dan saling berbagi dalam sistem budaya Jawa harus ditambah dengan tekad akan kelurusan hati untuk berbudi luhur jujur dan mampu menghargai perbedaan. Misalnya $\mathrm{Si} \mathrm{A}$ menendang $\mathrm{Si}$ B. Kemudian $\mathrm{Si}$ B mengadukan perbuatan Si A kepada orangtua atau guru maka penanganannya dengan mendamaikan keduanya. Orangtua atau guru memberikan pengertian kepada 
Si B bahwa mungkin Si A tidak sengaja menendang Si B. Selain itu orangtua atau guru juga memberikan kesempatan kepada $\mathrm{Si} A$ untuk menjelaskan alasan perbuatannya. Setelah itu orangtua atau guru meminta keduanya untuk berdamai.

Poin ketiga, baik budi. Untuk menekankan makna kelurusan hati dalam program SAHABAT, konsep baik budi menjadi penting. Makna yang merefleksikan konsep ini antara lain adalah nilai untuk melakukan perbuatan luhur, memberi dengan tulus, berbuat jujur, rendah hati, menerima apa adanya dan bersikap adil. Konsep baik budi sangat penting untuk diajarkan pada anak-anak karena baik budi mengajarkan kejujuran, kebenaran atau kesungguhan hati, menekankan kepercayaan, tidak memanipulasi dan mempunyai kesadaran akan sanksi sosial yang berat jika nilai ini dilanggar. Misalnya ketika terjadi bullying yaitu anak mencubit temannya maka penanganannya dengan guru dan orangtua mengajarkan kepada pelaku untuk berkata jujur dengan tindakan yang dilakukannya. Sedangkan bagi korban diajarkan untuk berkata jujur atas perilaku temannya. Kemudian keduanya diajarkan untuk bersikap adil dan memberi maaf dengan tulus.

Poin keempat, tanggung jawab. Konsep ini merefleksikan makna di mana anak dilatih untuk melakukan sesuatu dengan sebaik-baiknya sesuai tugasnya, membantu orang lain ketika mereka membutuhkan bantuan, menjaga, merawat diri sendiri/barang, menjaga orang lain yang membutuhkan, membantu menciptakan dunia yang lebih baik. Misalnya ketika terjadi bullying yaitu anak merusak barang milik temannya maka penanganannya guru dan orangtua meminta anak untuk bertanggung jawab dengan perbuatannya itu dengan meminta maaf dan berusaha mengembalikan barang seperti semula atau menggantinya.

Pastikan orang tua dan guru menerapkan berbagai macam nilai etika "SAHABAT" di atas dalam menangani masalah bullying. Dalam menerapkan nilai etika "SAHABAT" tidak dapat dipisahkan satu sama lain dan tidak dapat dijelaskan secara terpisah, nilai-nilai tersebut harus diterapkan melebur menjadi satu dalam proses penanganan perilaku bullying. Melalui program "SAHABAT" yaitu kasih SAyang, HArmonis, BAik budi dan Tanggung jawab diharapkan guru dan orang tua memiliki pengetahuan terkait cara mengatasi permasalahan bullying yang terjadi pada anak usia dini dan meminimalisir dampak bullying pada anak di sekolah.

\section{Penanganan Perilaku Bullying}

Perlu diingat bahwa dalam menangani perilaku bullying tidak hanya pelaku saja yang perlu untuk ditangani, akan tetapi yang menjadi korban pun perlu penanganan. Di bawah ini beberapa penanganan perilaku bullying menurut Heni (dalam http://heny.students.uii.ac.id/2012/12/15/b ullying/)

1. Penanganan bagi anak yang menjadi korban bullying

a. Mengajarkan kemampuan asertif, yaitu suatu kemampuan untuk mengkomunikasikan apa yang diinginkan, dirasakan, dan dipikirkan kepada orang lain namun dengan tetap menjaga dan menghargai hak-hak serta perasaan orang lain.

Orang dewasa perlu mengajarkan anak untuk menyampaikan pendapat atau opini pada orang lain dengan cara yang tepat. Hal ini termasuk kemampuan untuk mengatakan "tidak" atas tekanan-tekanan yang dialami saat dia merasa dirugikan.

Latih anak untuk menyatakan ketidaksukaan, ketidaksetujuan dan penolakan melalui ucapan. Anak-anak lain yang akan terus menyakiti apabila yang disakiti diam dan tidak mengungkapkan apa yang dirasakannya. Orang dewasa dapat berpesan "jika temanmu hendak menyakitimu, ajak temanmu bicara 
bahwa itu bisa membuat kamu sakit. Seperti "jangan begitu, itu membuatku sakit" atau "berhenti, itu sakit!". Keterampilan ini disebut keterampilan asertif.

b. Jika bullying berupa intimidasi verbal, anak perlu dilatih kemampuan mengendalikan pikiran. Kemampuan ini semacam membalikkan serangan kalimat negatif menjadi dimaknai lebih positif oleh anak-anak. Bantu anak membalasnya dengan kalimat-kalimat lain lebih positif. Misalnya:

B : Hei gendut...

A : Hai juga.. kurus.

B : Badanmu kayak gajah. Gede, hahaha

A :Iya tandanya aku tidak kekurangan makan, berkecukupan, Alhamdulillah.

B : Ih..pede banget.. nggak tau malu!

A :Ya dong pede.. aku kan punya banyak kelebihan

B : Iya, kelebihan berat badan! Hahaha

A : Daripada kekurangan gizi, kurus.. hahaha

B : Dasar jelek

A :Menurut orangtuaku, aku cakep tuh.

Sesuatu yang ditanggapi berulang-ulang dengan tenang dapat membuat pelaku bullying akan bosan dengan sendirinya. Sebisa mungkin anak dilatih untuk menyelesaikan masalah, bukan orangtua atau guru yang menyelesaikan masalah anak. Jika terus mendapatkan intimidasi berulang padahal yang mengintimidasi sudah diajak bicara tapi tidak juga menghentikkan aksi bullyingnya, latihlah anak untuk melawan. Melawan tidak berarti harus melukai orang lain. "Jika adikmu mau mukul, kamu pegang tangan adik, jangan biarkan dia memukulmu" atau "Jika temanmu hendak mendorongmu, kamu harus menghindar. Jangan pernah biarkan temanmu melukaimu". Jika anak tak mampu melawan, latih anak untuk melaporkan kepada guru dan orang tua. c. Asah percaya diri anak yaitu dengan mengatakan ia mampu menghadapi pelaku bullying, bila tidak mampu, lapor kepada guru atau orang tua.

d. Walau anak sudah diajarkan untuk mempertahankan diri dan dibekali kemampuan agar tidak menjadi korban tindak kekerasan, tetap beritahukan anak ke mana ia dapat melaporkan atau meminta pertolongan atas tindakan kekerasan yang ia alami (bukan saja bullying).

e. Yakinkan pada anak, jika anak tidak membalas maka kemungkinan besar perilaku tersebut akan berulang

f. Upayakan anak mempunyai kemampuan sosialisasi yang baik dengan teman sebaya atau dengan orang yang lebih tua. Dengan banyak berteman, diharapkan anak tidak terpilih menjadi korban bullying.

2. Penanganan bagi anak yang menjadi pelaku bullying:

a. Segera ajak anak bicara mengenai apa yang ia lakukan. Jelaskan bahwa tindakannya merugikan diri dan orang lain.

b. Minta anak untuk bertanggung jawab atas apa yang diperbuatnya. Misalnya, anak tersebut memukul, maka anak diminta untuk menenangkan si korban.

c. Minta anak untuk meminta maaf dan buat kesepakatan pada anak untuk tidak mengulangi perbuatannya.

d. Cari penyebab anak melakukan hal tersebut. Penyebab menjadi penentu penanganan. Anak yang menjadi pelaku karena rasa rendah diri tentu akan ditangani secara berbeda dengan pelaku yang disebabkan oleh dendam karena pernah menjadi korban. Demikian juga bila pelaku disebabkan oleh agresifitasnya yang berbeda.

e. Posisikan diri untuk menolong anak dan bukan menghakimi anak. 
Hal-hal yang perlu diperhatikan bagi orang tua atau wali orang tua jika anaknya menjadi korban bullying di sekolah di antaranya:

a. Satukan persepsi dengan istri/suami (kompak)

Sangat penting bagi suami-istri untuk satu suara dalam menangani permasalahan yang dihadapi anak-anak di sekolah. Karena kalau tidak, anak akan bingung, dan justru akan semakin tertekan. Kesamaan persepsi yang dimaksud meliputi beberapa așpek, misalnya: apakah orang tua perlu ikut campur terkadang anak sudah lupa dengan pertengakarannya tetapi orang tua masih mengungkit-ungkit, kemudian apakah orang tua perlu datang ke sekolah, apakah perlu menemui orang tua pelaku bullying.

b. Pelajari dan kenali karakter anak

Dengan mengenali karakter anak, kita akan bisa mengantisipasi berbagai potensi intimidasi yang menimpa anak, atau setidaknya lebih cepat menemukan solusi (karena kita menjadi lebih siap secara mental).

c. Jalin komunikasi dengan anak

Tujuannya adalah anak akan merasa cukup nyaman bercerita kepada kita sebagai orang tuanya ketika mengalami intimidasi di sekolah. Ini menjadi kunci berbagai hal, termasuk untuk memonitor apakah suatu kasus sudah terpecahkan atau belum.

d. Jangan terlalu cepat ikut campur

Idealnya, masalah antar anak-anak bisa diselesaikan sendiri oleh mereka, termasuk di dalamnya kasus-kasus bullying. Oleh karena itu, prioritas pertama memupuk keberanian dan rasa percaya diri pada anak-anak kita (yang menjadi korban bullying).

e. Masuklah di saat yang tepat

Jangan lupa, bahwa seringkali anak (yang menjadi korban bullying tidak senang kalau kita (orang tuanya) turut campur. Oleh karena itu, kita mesti benar-benar mempertimbangkan saat yang tepat ketika memutuskan untuk ikut campur menyelesaikan masalah.

f. Bicaralah dengan orang yang tepat

Jika sudah memutuskan untuk ikut campur dalam menyelesaikan masalah, pertimbangkan masak-masak apakah akan langsung berbicara dengan pelaku intimidasi, orang tuanya, atau gurunya.

g. Jangan ajari anak lari dari masalah

Dalam beberapa kasus yang diceritakan teman-teman saya, anakanak kadang merespon intimidasi yang dialaminya di sekolah dengan minta pindah sekolah. Kalau dituruti, itu sama saja dengan lari dari masalah. Jadi, sebisa mungkin jangan dituruti. Kalau ada masalah di sekolah, masalah itu yang mesti diselesaikan, bukan dengan 'lari' ke sekolah lain. Jangan lupa, bahwa kasus-kasus bullying itu terjadi hampir di semua sekolah.

\section{Penutup}

Guru dan orang tua perlu bersinergi dalam upaya mengatasi perilaku bullying yang terjadi di sekolah, salah satunya dengan menerapkan program SAHABAT. Melalui program "SAHABAT" yaitu kasih SAyang, HArmonis, BAik budi dan Tanggung jawab diharapkan guru dan orang tua memiliki pengeratuan terkait cara mengatasi permasalahan bullying yang terjadi pada anak usia dini. Dengan terlaksananya program SAHABAT, diharapkan pembelajaran di sekolah dapat berlangsung dengan lebih baik, suasana yang menyenangkan pun dapat membantu perkembangan sosial-emosional anak agar berkembang dengan baik. 


\section{Daftar Rujukan}

Egi. ( 2012). Perilaku Bullying Pada Anak Sekolah. Diakses dari http://regianamanah.blogspot.com/ 2011/02/perilaku-bullying-padaanak-sekolah.html.

Heni Gnamy. (2012). Bullying. Diakses dari

http://heny.students.uii.ac.id/2012/ 12/15/bullying/).
Jenny Gichara. (2006). Mengatasi Perilaku Buruk Anak. Jakarta: Kawan Pustaka.

Ponny Retno Astuti. (2008). Meredam Bullying. Jakarta: Grasindo.

Slamet Suyanto. (2005). Dasar-Dasar Pendidikan Anak Usia Dini. Yogyakarta: Hikayat Publishing. 